\title{
Intrinsic labelling of chicken meat with stable isotopes of zinc, for intended use in human feeding studies: feasibility and design considerations
}

\author{
BY MORTEZA JANGHORBANI, BILL T. G. TING \\ AND VERNON R. YOUNG
}

Nuclear Reactor Laboratory and Department of Nutrition and Food Science, Massachusetts Institute of Technology, Cambridge, Massachusetts 02139, USA

\author{
AND FRED H. STEINKE
}

Central Research Division, Ralston Purina Company, St Louis, Missouri 63188, USA

(Received 5 January 1981 - Accepted 28 May 198I)

1. The feasibility of intrinsically labelling poultry meat with the stable isotopes ${ }^{\circ} \mathrm{Zn}$ and ${ }^{70} \mathrm{Zn}$ was investigated.

2. Chickens (1-d-old) were gavaged with solutions of ${ }^{67} \mathrm{Zn}$ and ${ }^{70} \mathrm{Zn}$ several times over a $42 \mathrm{~d}$ period.

3. Isotopic analysis of edible tissues has shown that they were significantly enriched with respect to the gavaged isotope and that the extent of isotopic enrichment achieved was sufficient to permit their use in human feeding experiments designed to investigate availability of native $\mathrm{Zn}$ from such food models.

4. The absolute efficiency of retention of the stable isotopes from gavage solutions in the edible tissues has been calculated to be $2-3 \%$ of the administered dose; methods have been suggested to enhance this value, based on considerations of utilization of dietary $\mathbf{Z n}$.

The availability of zin: from foods is an important determinant of the requirement for the mineral (Sandstead, 1973). In addition to the absolute level of $\mathrm{Zn}$ in the diet, several dietary factors may influence the availability of the element (O'Dell, 1969). Thus, the nature of the particular food might be an important determinant of the extent of its $\mathrm{Zn}$ absorption. However, it has not yet been established conclusively whether all $\mathrm{Zn}$ in a composite meal behaves as a single exchangeable pool at the absorption site. Evans \& Johnson (1977) compared absorption of ${ }^{65} \mathrm{Zn}$-labelled maize and rat liver preparations in rats with that from a similar diet in which ${ }^{65} \mathrm{Zn}$ was added extrinsically and found that absorption of the two isotope preparations was similar. However, their studies involved comparison of results with different groups of animals and so a direct test was not performed to evaluate the exchangeability of different pools of $\mathrm{Zn}$ within the intestine. Furthermore, the extent to which their results can be extrapolated to man is uncertain. Therefore, no direct evidence yet exists in reference to the exchangeability of $\mathrm{Zn}$ in composite meals in man similar to that already established for dietary iron (Cook et al. 1972).

Direct measurement of food $\mathrm{Zn}$ absorption in man has been made with isotopic labelling of the diet, either with radio-Zn (Sandstrom et al. 1980) or, more recently, with stable isotopes of the mineral (Janghorbani \& Young, 1980). In this method it is now assumed that an extrinsically-a.dded isotopic solution of $\mathrm{Zn}$ exchanges isotopically with the food $\mathrm{Zn}$ before absorption, and this provides an accurate measure of absorption of the native $\mathrm{Zn}$ from the food, an assumption whose validity has not yet been tested in man.

The need for establishing the validity of the extrinsic tag approach is especially crucial when stable isotopes are employed because these are used not at tracer levels but at levels approaching substrate values.

Preparation of foods biologically labelled with stable isotopes involves several issues not 
associated with radio-labelling experiments, and their implications are different for different minerals and various foods (Janghorbani, Christensen et al. 1980). Specifically in regard to $\mathrm{Zn}$, five stable isotopes are currently available as highly-enriched preparations and in theory lend themselves to biological labelling. This paper describes the biological labelling of poultry meat with stable isotopes of $\mathrm{Zn}$ for use in human feeding experiments.

\section{METHODS}

\section{Stable isotopes}

Stable isotopes ${ }^{70} \mathrm{Zn}$ (atomic enrichment $65.5 \%$ ) and ${ }^{68} \mathrm{Zn}$ (atomic enrichment $99.0 \%$ ) were purchased from Oak Ridge National Laboratory, Oak Ridge, TN, USA. The isotopes were dissolved in a small amount of concentrated hydrochloric acid and diluted to provide a zinc chloride solution for gavage.

\section{Labelling procedure}

Broiler type chicks (1-d-old) were obtained from a commercial hatchery and housed in electrically-heated, wire-bottom batteries at the Ralston Purina Research Laboratories. Temperature in the batteries was maintained at $32^{\circ}$ for the first 2 weeks and then reduced to room temperature of $24^{\circ}$. The diet was a simplified maize-soya-bean-meal broiler starter ration which met all of the (US) National Research Council (1977) requirements for broiler chickens except $\mathrm{Zn}$ and contained $230 \mathrm{~g}$ protein (nitrogen $\times 6.25$ ) $/ \mathrm{kg}$. The $\mathrm{Zn}$ content of the food was determined to be $18 \mathrm{mg} / \mathrm{kg}$ and was adjusted with inorganic $\mathrm{Zn}$ supplement to correspond to values given in Table 1 .

Table 1. Gavage schedule and zinc intake for chickens receiving ${ }^{70} \mathrm{Zn}$ and ${ }^{68} \mathrm{Zn}$

\begin{tabular}{|c|c|c|c|}
\hline Age of chicken (d) & $\begin{array}{c}\text { Dietary zinc } \\
\text { content }(\mathrm{mg} / \mathrm{kg})\end{array}$ & $\begin{array}{c}\text { Gavage dose } \\
\left(\mathrm{mg}{ }^{{ }^{88}} \mathrm{Zn} \text { or }{ }^{70} \mathrm{Zn} / \text { dose) }\right.\end{array}$ & $\begin{array}{c}\text { No. of } \\
\text { gavages/period }\end{array}$ \\
\hline \multicolumn{4}{|c|}{${ }^{70} \mathrm{Zn}$ group } \\
\hline $0-21$ & 40 & 0 & 0 \\
\hline $22-28$ & 25 & $1 \cdot 26$ & 3 \\
\hline $29-35$ & 25 & $2 \cdot 20$ & 3 \\
\hline $36-43$ & 20 & $2 \cdot 69$ & 3 \\
\hline \multicolumn{4}{|c|}{${ }^{68 Z n}$ group } \\
\hline $0-14$ & 40 & 0 & 0 \\
\hline $14-28$ & 20 & $4 \cdot 8$ & 6 \\
\hline $29-43$ & 20 & 6.6 & 6 \\
\hline
\end{tabular}

Two chickens were used in enrichment trials with ${ }^{70} \mathrm{Zn}$ and three with ${ }^{68} \mathrm{Zn}$. Details of the gavage procedure for the two isotopes are given in Table 1 . A total of $18.5 \mathrm{mg}{ }^{70} \mathrm{Zn}$ was gavaged per chicken while the corresponding value was $68.4 \mathrm{mg}$ for ${ }^{68} \mathrm{Zn}$.

At $43 \mathrm{~d}$ of age, the chickens were killed, bled, eviscerated, chilled in ice and placed in bags for shipment to Massachusetts Institute of Technology. Dressed weights of the ${ }^{70} \mathrm{Zn}$-enriched chickens were 670 and $470 \mathrm{~g}$ and for the ${ }^{68} \mathrm{Zn}$-enriched chickens the weights were 730,740 and $755 \mathrm{~g}$.

\section{Isotopic analyses}

On opening the bags, duplicate samples from each tissue (heart, gizzard, liver, breast meat, and leg meat) were taken with a clean stainless-steel blade, blotted with tissue paper and weighed accurately. Each sample was then wet ashed and analyzed for its ${ }^{68} \mathrm{Zn}$ and ${ }^{70} \mathrm{Zn}$ 
isotopic composition using the method of Radiochemical Neutron Activation Analysis (RNAA) as described : $n$ detail previously (Janghorbani, Christensen et al. 1980). The results for each sample were then calculated as $\mu \mathrm{g}$ of isotope per $\mathrm{g}$ fresh weight of the tissue or mass isotopic ratio of ${ }^{70} \mathrm{Zn}$ to ${ }^{88} \mathrm{Zn}$ in the tissue.

\section{RESULTS AND DISCUSSION}

Selection of isotope for labelling. Five stable isotopes of $\mathrm{Zn}$ are currently available as highly-enriched preparations (Oak Ridge National Laboratory) and details are given in Fig. 1. As also indicated in Fig. 1 and discussed in detail elsewhere (Janghorbani \& Young 1981), the analytical measurement method now available for routine application of stable isotopes of $\mathrm{Zn}$ to human nutrition is based on neutron-activation analysis. This method can measure only the three stable isotopes ${ }^{64} \mathrm{Zn},{ }^{68} \mathrm{Zn}$ and ${ }^{70} \mathrm{Zn}$ through the measurement of their neutron-activation products ${ }^{65} \mathrm{Zn},{ }^{69 \mathrm{~m}} \mathrm{Zn}$ and ${ }^{71 \mathrm{~m}} \mathrm{Zn}$ respectively. In a typical human feeding experiment designed to test the validity of the extrinsic tag approach, the diet is enriched intrinsically with one isotope, extrinsically with a second isotope, and a third isotope is also measured in the diet and the faeces in order to account for endogenous sources of the first two isotopes (see p. 400). Of the three isotopes which can be measured with neutron-activation analysis, ${ }^{64} \mathrm{Zn}$ has a relatively high natural abundance and thus will not permit enrichment in the chicken tissues by better than a factor of two. In addition, because of its relatively high natural abundance and its favourable neutron-activation characteristics, it is ideally suited as the isotope to be measured in order to account for endogenous $\mathrm{Zn}$. Of the two remaining isotopes, i.e. ${ }^{68} \mathrm{Zn}$ and ${ }^{70} \mathrm{Zn}$, both appear potentially useful for labelling experiments despite the apparent large differences in their natural isotopic abundances. For

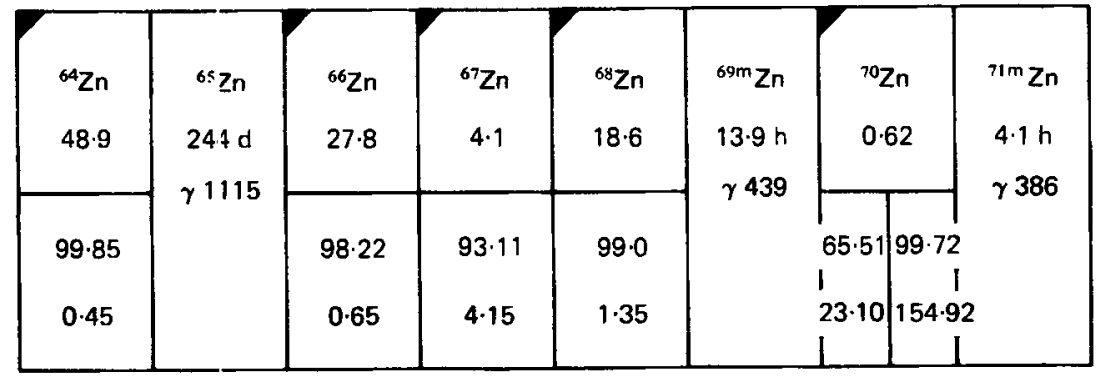

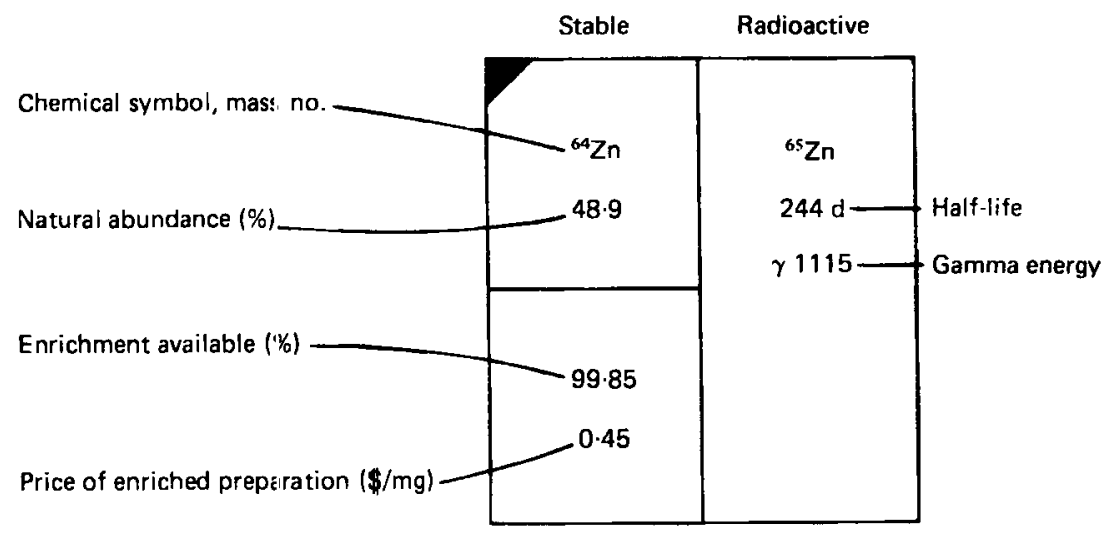

Fig. 1. Diagram showing isotopic constitution of zinc. 
Table 2. Typical values $\left(\mu \mathrm{g} / \mathrm{g}\right.$ fresh weight) for ${ }^{68} \mathrm{Zn}$ and ${ }^{70} \mathrm{Zn}$ in tissues of chickens from test groups

(Mean values for duplicate analyses)

\begin{tabular}{|c|c|c|c|c|c|}
\hline $\begin{array}{c}\text { Chicken } \\
\text { no. }\end{array}$ & Test Group & Tissue & ${ }^{68} \mathrm{Zn}$ & ${ }^{70} \mathrm{Zn}$ & $\begin{array}{l}\text { Mass isotope } \\
\text { ratio, }{ }^{70} \mathrm{Zn}:{ }^{88} \mathrm{Zn}^{*}\end{array}$ \\
\hline 927 & ${ }^{70} \mathrm{Zn}$-enriched & $\begin{array}{l}\text { Liver } \\
\text { Gizzard } \\
\text { Heart } \\
\text { Skin } \\
\text { Leg meat } \\
\text { Breast meat }\end{array}$ & $\begin{array}{l}7.33 \\
3.99 \\
3.89 \\
1.91 \\
3.05 \\
0.90\end{array}$ & $\begin{array}{c}11.2 \\
4.09 \\
4.59 \\
1.49 \\
2.35 \\
0.76\end{array}$ & $\begin{array}{l}1.53 \\
1.03 \\
1.18 \\
0.78 \\
0.77 \\
0.84\end{array}$ \\
\hline 928 & ${ }^{68} \mathrm{Zn}$-enriched & $\begin{array}{l}\text { Liver } \\
\text { Gizzard } \\
\text { Heart } \\
\text { Skin } \\
\text { Leg meat } \\
\text { Breast meat }\end{array}$ & $\begin{array}{c}11 \cdot 5 \\
11 \cdot 1 \\
8.39 \\
3.58 \\
7.13 \\
1.96\end{array}$ & $\begin{array}{l}0.181 \\
0.123 \\
0.108 \\
0.060 \\
0.105 \\
0.025\end{array}$ & $\begin{array}{l}0.0157 \\
0.0111 \\
0.0129 \\
0.0168 \\
0.0147 \\
0.0128\end{array}$ \\
\hline
\end{tabular}

* Natural mass isotopic ratio 0.0344 .

Table 3. Isotopic analyses of chickens enriched with ${ }^{70} \mathrm{Zn}$ and ${ }^{68} \mathrm{Zn}$

(Mean values for duplicate analyses, expressed as mass isotope ratio, ${ }^{70} \mathrm{Zn}:{ }^{88} \mathrm{Zn}^{*}$ )

\begin{tabular}{|c|c|c|c|c|c|c|c|}
\hline $\begin{array}{c}\text { Chicken } \\
\text { no. }\end{array}$ & $\begin{array}{l}\text { Enriched } \\
\text { isotope }\end{array}$ & Liver & Gizzard & Heart & Skin & $\begin{array}{c}\text { Leg } \\
\text { meat }\end{array}$ & $\begin{array}{c}\text { Breast } \\
\text { meat }\end{array}$ \\
\hline 926 & ${ }^{70} \mathrm{Zn}$ & 0.651 & 0.555 & 0.577 & 0.401 & 0.434 & 0.429 \\
\hline 927 & ${ }^{70} \mathrm{Zn}$ & 1.53 & 1.03 & $1 \cdot 18$ & 0.780 & 0.771 & 0.844 \\
\hline \multirow{2}{*}{$927: 926$} & - & $2 \cdot 4$ & 1.9 & $2 \cdot 0$ & $2 \cdot 0$ & 1.8 & $2 \cdot 0$ \\
\hline & Mean $2 \cdot 0 \pm 0.2$ & & & & & & \\
\hline 928 & ${ }^{8 B} \mathrm{Zn}$ & 0.0157 & 0.0111 & 0.0129 & 0.0168 & 0.0147 & 0.0128 \\
\hline 930 & ${ }^{68} \mathrm{Zn}$ & 0.0109 & 0.0135 & 0.0112 & 0.0144 & 0.0123 & 0.0135 \\
\hline 931 & ${ }^{68} \mathrm{Zn}$ & 0.0133 & 0.0139 & 0.0138 & 0.0106 & 0.0130 & 0.0134 \\
\hline
\end{tabular}

* Natural mass isotopic ratio, ${ }^{70} \mathrm{Zn}:{ }^{68} \mathrm{Zn} 0.0344$.

these reasons, these two isotopes were selected for evaluation in labelling experiments reported here.

Accuracy of isotopic analyses. The accuracy and precision of the method used depends on the isotopic ratio for ${ }^{70} \mathrm{Zn} /{ }^{68} \mathrm{Zn}$ in the tissues (Janghorbani, Ting et al. 1980). In the present work, we anticipate the measured isotopic ratios to possess relative precisions of approximately $5 \%$ for the tissues enriched with ${ }^{70} \mathrm{Zn}$ and $10-20 \%$ for those enriched with ${ }^{68} \mathrm{Zn}$.

Achieved extent of isotopic enrichment. The mass isotopic ratio, ${ }^{70} \mathrm{Zn}:{ }^{68} \mathrm{Zn}$ in unenriched tissues is 0.0344 (Lederer et al. 1967). Typical isotopic analysis of the various tissues of one chicken from each isotope group are summarized in Table 2. Examination of these values revealed that there was a parallel difference in the concentration of the $\mathrm{Zn}$ isotopes among the various tissues. Thus, liver contained the highest levels of both isotopes while breast meat was lowest in its concentration of both $\mathrm{Zn}$ isotopes. The expected $\mathrm{Zn}$ concentration difference between dark and light meat (Underwood, 1977) was readily observed for both isotopes from either group. 
A summary of tissue isotopic enrichment values for all chickens from the two groups is given in Table 3. As evident, significant enrichment with ${ }^{70} \mathrm{Zn}$ or ${ }^{68} \mathrm{Zn}$ was achieved in both groups. For example, the mass isotopic ratio for ${ }^{70} \mathrm{Zn}:{ }^{68} \mathrm{Zn}$ in liver of chicken no. 927 was 1.53 compared with the unenriched isotope ratio of 0.0344 , or a 45 -fold enrichment with respect to ${ }^{70} \mathrm{Zn}$. Similarly, the corresponding value in liver of chicken no. 931 was 0.0133 , or a threefold enrichment with respect to ${ }^{68} \mathrm{Zn}$. Furthermore, the extent of enrichment achieved with ${ }^{70} \mathrm{Zn}$ was several times greater than that with ${ }^{68} \mathrm{Zn}$ and this was a consequence of the much greater dietary enrichment for the ${ }^{70} \mathrm{Zn}$ group (Table 1). Comparing the two chickens in the ${ }^{70} \mathrm{Zn}$ group, it was clear that tissue enrichment was greater in chicken no. 927 than in chicken no. 926 by a factor of approximately 2 (Table 3 ). Similarly, native $\mathrm{Zn}$ concentrations were al:so higher in tissues of chicken no. 927 than for chicken no. 926 . No such differences were observed among the ${ }^{68} \mathrm{Zn}$-enriched chickens. Since the dressed weight of chicken no. 927 was significantly smaller than for chicken no. $926(470 \mathrm{~g} \mathrm{v.} 670 \mathrm{~g})$ and no such differences were observed for the ${ }^{68} \mathrm{Zn}$ group, the observed differential enrichment between the ${ }^{70} \mathrm{Zn}$-enriched chickens was in part due to differences in body size. Moreover, for the ${ }^{70} \mathrm{Zn}$ group, preferential tissue enrichment was observed in the following sequence: liver $>$ heart $>$ gizzard $>$ skin $\approx$ leg meat $\approx$ breast meat. This was probably related to the lack of sufficient time for whole-body equilibration of the isotope before death and this effect would have been expected to be more pronounced for the ${ }^{70} \mathrm{Zn}$ group than for the ${ }^{68} \mathrm{Zn}$ group.

Due to the relatively high cost of isotopes associated with biological labelling of foods with $\mathrm{Zn}$, it is important to estimate the efficiency of incorporation of the isotopes in the edible tissues. It was estimated that $1 \cdot 6-3 \cdot 2 \%$ of the gavaged dose was retained in the edible tissues of these chickens (meat + skin + heart + liver + gizzard). These results clearly showed that efficiency of retention of the label in this procedure was low, resulting in wastage of approximately $97-98 \%$ of the gavaged isotope. Average $\mathrm{Zn}$ retention from the food in normal broilers, weighing approximately $1500 \mathrm{~g}$ at 6 weeks and consuming $2500 \mathrm{~g}$ food with a $\mathrm{Zn}$ content of $30 \mathrm{mg} / \mathrm{kg}$ (Scott et al. 1969) was calculated to be approximately 8-10\% of $\mathrm{Zn}$ intake in the ecible tissues. Thus, it appeared that had the enriched isotope been incorporated into the food under normal conditions of food consumption and broiler growth, isotope retention would probably have been greater than achieved with the present gavage procedure. However, even under such conditions, about $90 \%$ of the dose would have been excreted. Since it is well established that retention of ${ }^{65} \mathrm{Zn}$ given to chicks with relatively low dietary $\mathrm{Zn}$ intake is higher than for birds receiving an adequate $\mathrm{Zn}$ intake (Scott et al. 1969), incorporation of the label into food low in native $\mathrm{Zn}$ would be expected to provide the most efficient vehcle for incorporation of the isotope. For example, the entire $\mathrm{Zn}$ requirement of a bird could be satisfied with the $68.4 \mathrm{mg}{ }^{68} \mathrm{Zn}$ which was gavaged in the ${ }^{68} \mathrm{Zn}$ group. This would correspond, on the average, to a food $\mathrm{Zn}$ concentration of approximately $30 \mathrm{mg} / \mathrm{kg}$ which is sufficient for good growth. However, such a procedure necessitates use of foods low in native $\mathrm{Zn}$.

The levels of isotopic $\mathrm{Zn}$ gavaged in both groups combined with the food $\mathrm{Zn}$ concentrations (Table 1) correspondec to physiologically relevant intake levels for these birds. On average, the total $\mathrm{Zn}$ intake of these birds corresponded to $33-39 \mathrm{mg} / \mathrm{kg}$ for the ${ }^{70} \mathrm{Zn}$ group and approximately $55 \mathrm{mg} / \mathrm{kg}$ for the ${ }^{68} \mathrm{Zn}$ group so that incorporation of the isotope in various tissues was expected to have followed a pattern similar to that from normal levels of $\mathrm{Zn}$ supplementation.

Implications for studies in humans. Measurement of $\mathrm{Zn}$ absorption from the intrinsicallylabelled food using the method of stable isotopes and faecal monitoring requires accurate estimation of the intak 2 of enriched isotope and a second isotope from the enriched dietary pool, as well as both isotopes in the entire faecal pool (Janghorbani, Ting et al. 1980). These 
concepts have been discussed previously and the expression used to calculate fractional absorption $(F)$ of the enriched isotope from the enriched dietary pool (Janghorbani, Ting et al. 1980) is given as

$$
F=\frac{A_{0,1}^{*}-A_{f t, 1}+R_{1,2} \cdot A_{f t, 2}-R_{1,2} \cdot A_{0,2}^{*}}{A_{0,1}^{*}-R_{1,2} \cdot A_{0,2}^{*}}
$$

where $A_{0,1}^{*}$ and $A_{0,2}^{*}$ are the intake doses of the two isotopes of interest in the enriched diet pool, $A_{0,1}^{*}$ is intake dose of enriched isotope, $A_{f t, 1}$ and $A_{f t, 2}$ are the total isotope contents of faecal pool and $R_{1,2}$ is the natural isotope ratio, isotope 1 :isotope 2 .

In the instance of intrinsically-labelled foods $A_{0,2}^{*}$ was not likely to be negligible and could not be ignored in the equation. Furthermore, the value $A_{0,1}^{*}: A_{0,2}^{*}$ would by necessity be smaller than for extrinsic tag experiments. In addition, the total quantities of unabsorbed $A_{0,1}^{*}$ and $A_{0,2}^{*}$ would be further diluted in the faecal pool by the respective isotopes originating from the basal diet and via endogenous secretions. The consequences of this over-all isotopic dilution would result in increased contribution of the measurement uncertainty $\left(\sigma_{F} / F\right.$; Janghorbani, Ting $e t$ al. 1980$)$ to the over-all experimental uncertainty of the estimated value of $F$. The appropriate mathematical expression for estimating this measurement uncertainty has been given previously (Janghorbani, Ting et al. 1980) which allows realistic determination of the minimum measurement error involved under any given set of feeding and measurement conditions. In evaluating the adequacy of a given enrichment achieved for an intrinsically-labelled food, it is important to calculate this contribution to the over-all uncertainty of $F$, since the measurement uncertainty must be small compared to any biological variability.

The expected variability $\left(\sigma_{F} / F\right)$ resulting from the over-all measurement precision for the labelled chickens whose isotopic compositions are typical of the values reported in the present paper is presented for various experimental conditions in Table 4. In Table 4, it has been assumed that either all meat or the white meat portion from a single chicken whose isotopic information conformed to the average values given in Tables 5 and 6 were given

Table 4. Expected measurement error $\left(\sigma_{\mathrm{F}} / \mathrm{F}\right)$ in the estimation of fractional absorption*

\begin{tabular}{|c|c|c|c|c|}
\hline Case no. & Feeding regimen & $\begin{array}{l}\text { Enriched } \\
\text { isotope }\end{array}$ & $\begin{array}{c}\text { Over-all } \\
\text { measurement } \\
\text { precision }(\%)\end{array}$ & $\sigma_{F} / F$ \\
\hline 1 & $\begin{array}{l}\text { All meat, } 15 \mathrm{mg} / \mathrm{d} \\
\mathrm{Zn} \text { supplement }\end{array}$ & ${ }^{70} \mathrm{Zn}$ & 5 & 0.26 \\
\hline 2 & $\begin{array}{l}\text { All meat, } 15 \mathrm{mg} / \mathrm{d} \\
{ }^{64} \mathrm{Zn} \text { supplement }\end{array}$ & ${ }^{30} \mathrm{Zn}$ & 5 & 0.16 \\
\hline 3 & $\begin{array}{l}\text { All meat, } 15 \mathrm{mg} / \mathrm{d} \\
{ }^{84} \mathrm{Zn} \text { supplement }\end{array}$ & ${ }^{70} \mathrm{Zn}$ & 1 & 0.03 \\
\hline 4 & $\begin{array}{l}\text { White meat only, } 15 \mathrm{mg} / \mathrm{d} \\
{ }_{64} \mathrm{Zn} \text { supplement }\end{array}$ & ${ }^{70} \mathrm{Zn}$ & 5 & 0.29 \\
\hline 5 & $\begin{array}{l}\text { White meat only, } 15 \mathrm{mg} / \mathrm{d} \\
{ }^{84} \mathrm{Zn} \text { supplement }\end{array}$ & ${ }^{70} \mathrm{Zn}$ & 1 & 0.06 \\
\hline 6 & $\begin{array}{l}\text { All meat, } 15 \mathrm{mg} / \mathrm{d} \\
{ }^{64} \mathrm{Zn} \text { supplement }\end{array}$ & ${ }^{88} \mathrm{Zn}$ & 5 & 0.60 \\
\hline 7 & $\begin{array}{l}\text { All meat, } 15 \mathrm{mg} / \mathrm{d} \\
{ }^{64} \mathrm{Zn} \text { supplement }\end{array}$ & ${ }^{88} \mathrm{Zn}$ & 1 & 0.12 \\
\hline
\end{tabular}

* Assumptions: (1) Recommended daily allowance $15 \mathrm{mg}$ (Sandstead, 1973), (2) $\mathrm{Zn}$ is in balance; daily faecal output = daily intake, (3) supplementation is such that total daily intake of $\mathrm{Zn}$ is $15 \mathrm{mg}$ for the entire duration of the experiment, thus, on days of jsotope administration, supplement is less than $15 \mathrm{mg}$ by the amount of $\mathrm{Zn}$ supplied from the chicken. 
Table 5. Tissue zinc concentrations ( $\mu \mathrm{g} \mathrm{Zn} / \mathrm{g}$ fresh tissue) of various chickens

(For chickens nos. 9:6 and 927 the $\mathrm{Zn}$ content was calculated based on ${ }^{88} \mathrm{Zn}$ isotopic analyses, for the other chickens total $\mathrm{Zn}$ content was based on ${ }^{70} \mathrm{Zn}$ isotopic analyses)

\begin{tabular}{cccc}
\hline \hline Chick:en no. & Liver & Leg meat & Breast meat \\
\hline 926 & 28.4 & 11.7 & 13.9 \\
927 & 38.0 & 15.8 & 4.7 \\
928 & 27.2 & 15.8 & 3.8 \\
930 & 48.1 & 13.6 & 4.2 \\
931 & 23.8 & 14.6 & 4.5 \\
Mean \pm 1 sD & $33.1 \pm 9.9$ & $14.3 \pm 1.7$ & $6.2 \pm 4.3$ \\
\hline \hline
\end{tabular}

Table 6. Isotopic contribution ( $\mu \mathrm{g})$ to daily intake of zinc*

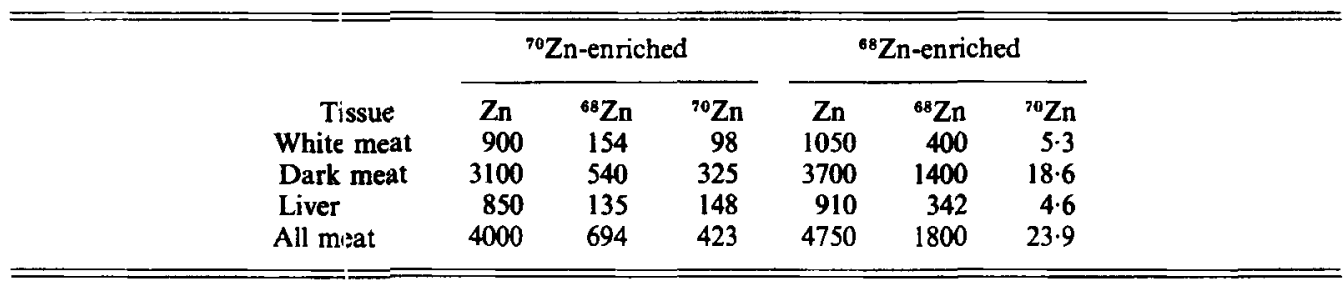

* Assumptions: body-weight $1200 \mathrm{~g}$, white meat $200 \mathrm{~g}$, dark meat $200 \mathrm{~g}$, liver $20 \mathrm{~g} ; \mathrm{Zn}$ concentrations $(\mu \mathrm{g} / \mathrm{g}$ fresh weight): white meat 4 , dark meat 14, liver 33; data based on analyses of this work for a single chicken.

to a subject in a single test meal. The expected value of $\sigma_{F} / F$ under several realistic sets of intake conditions was calculated using the expression described previously (Janghorbani, Ting et al. 1980). For instance, all meat from a ${ }^{70} \mathrm{Zn}$-enriched chicken may be used to provide a daily total $\mathrm{Zn}$ intake of approximately $4 \mathrm{mg}$ (Table 6). If the diet were then supplemented with an additional $11 \mathrm{mg} \mathrm{Zn}$ on the day of isotope administration to bring the total $\mathrm{Zn}$ intake up to the recommended level and $15 \mathrm{mg} \mathrm{Zn}$ on other days and assuming that a faecal pool corresponding to approximately $3 \mathrm{~d} \mathrm{Zn}$ intake would be sufficient to recover all unabsorbed isotope and accepting measurement precision of $5 \%$ (case no. 1, Table 4), the value for $\sigma_{F} / F$ was $0 \cdot 26$. This value was unacceptably large and resulted partly from the dilution of the enriched food with the supplemented $\mathrm{Zn}$. On the other hand, if the dilution of the enriched isotope was eliminated by supplementing the diet with ${ }^{64} \mathrm{Zn}$ (which can be purchased at $100 \%$ enrichment for $\$ 0.45 / \mathrm{mg}$ ) instead of $\mathrm{Zn}$ under the same supplementation conditions as described previously, the value of $\sigma_{F} / F$ could be expected to be reduced to 0.16 (case no. 2, Table 4). In addition, if measurement precision was approximately $1 \%$ (case no. 3, Table 4), there was a dramatic improvement in $\sigma_{F} / F$ to 0.03 . This indicated that in order to use successfully chickens intrinsically-labelled with ${ }^{70} \mathrm{Zn}$, any dietary supplement with $\mathrm{Zn}$ must be made such that dilution of the enriched isotope is minimized and the isotopic analyses must be carried out with analytical precisions approaching $1 \%$. Similar calculations inidicate that for ${ }^{70} \mathrm{Zn}$-enriched chickens it would be possible to use only part of the meat (case no. 5, Table 4) and so allow determination of the availability of $\mathrm{Zn}$ in different types of muscle, for example, but here the analytical measurement precision would have to reach $1 \%$.

In contrast, the extent of enrichment achieved with ${ }^{88} \mathrm{Zn}$ in chickens nos. $928-930$ was marginal for use in human studies (cases nos. 6 and 7, Table 4) unless either a higher portion 
of the recommended $\mathrm{Zn}$ intake was supplied from the enriched chickens, a greater extent of ${ }^{68} \mathrm{Zn}$ enrichment was achieved through more efficient utilization of the enriched isotope, or the analytical measurement precision was close to $1 \%$, all of which could, in principle, be achieved. This is, of course, due to the fact that if body $\mathrm{Zn}$ homoeostasis is maintained via secretion of the element into the intestinal lumen a significant fraction of total faecal ${ }^{68} \mathrm{Zn}$ arises from these secretions and elimination of ${ }^{68} \mathrm{Zn}$ from the dietary supplement does not effectively reduce dilution of the enriched isotope.

\section{SUMMARY AND CONCLUSIONS}

The feasibility experiments reported here indicate that: (1) intrinsic labelling of edible chicken tissues with stable isotopes of $\mathrm{Zn}$ can be realistically achieved on a scale sufficient to allow use in human metabolic studies; (2) the absolute isotopic utilization of the enriched isotope in the present experiments is low, resulting in high wastage of the administered isotope. However, improvements can be made by incorporation of the $\mathrm{Zn}$ isotope into the food, rather than using a gavage procedure; (3) based on cost analyses and other considerations, ${ }^{68} \mathrm{Zn}$ appears to be the prefered isotope for labelling purposes. Isotopic cost for labelling a single bird can be reduced to below $\$ 100$; (4) measurement methodology now is available to permit routine investigation of double-labelling of diets with stable isotopes of $\mathrm{Zn}$. This would allow resolution of issues concerned with exchangeability of $\mathrm{Zn}$ pools in the lumen of the intestine and this offers exciting opportunities for exploring the bioavailability of dietary $\mathrm{Zn}$ in human subjects under a wide range of nutritional conditions.

This work was done in part under the NSF grant no. 7919112-PFR, and NIH grant no. 1-RO1-CA-27917-01. Morteza Janghorbani, Bill T. G. Ting and Vernon R. Young greatly appreciated all the assistance given by the Ralston-Purina Company, St Louis during the conduct of the experiments.

\section{REFERENCES}

Cook, J. D., Layrisse, M., Martinez-Torres, C., Walkes, R., Monsen, E. \& Finch, C. A. (1972). J. clin. Invest. $51,805$.

Evans, G. W. \& Johnson, P. E. (1977). Am. J. clin. Nutr. 30, 873.

Janghorbani, M., Christensen, M. J., Steinke, F. H. \& Young, V. R. (1980). J. Nutr. $111,817$.

Janghorbani, M., Ting, B. T. G. \& Young, V. R. (1980). Clin. chim. Acta 108, 9.

Janghorbani, M. \& Young, V. R. (1980). In Advances in Nutritional Research, Vol. 3, p. 127 [H. H. Draper, editor]. New York: Plenum Press.

Janghorbani, M. \& Young, V. R. (1981). Proc. int. Conf. Clinical and Public Health Significance of Trace Minerals in the World Population, Detroit, 1980 (In the Press).

Lederer, C. M., Hollander, J. M. \& Perlman, I. (1967). Table of Isotopes, 6th ed. New York: John Wiley.

O'Dell, B. L. (1969). Am. J. clin. Nutr. 22, 1315.

Sandstead, H. H. (1973). Am. J. clin. Nutr. 26, 1251.

Sandstrom, B., Arvidsson, B., Cederblad, A. \& Bjorn-Rasmussen, E. (1980). Am. J. clin. Nutr. $33,739$.

Scott, M. L., Nesheim, M. C. \& Young, R. J. (1969). Nutrition of the Chicken. Ithaca, New York: M. L. Scott \& Associates.

Underwood, E. J. (1977). Trace Elements in Human and Animal Nutrition, 4th ed. New York: Academic Press. 